\title{
COMPARATIVE STUDY OF THE MANDARIN HYBRID FRUIT CHARACTERISTICS: NOVA, MURCOTT AND ORTANIQUE IN CAPÃO BONITO - SP, BRAZIL ${ }^{1}$
}

\author{
ROGÉRIO DE SÁ BORGES² \& ROSE MARY PIO ${ }^{3}$
}

\begin{abstract}
The Murcott tangor represent 20\% of the tangerines trees in São Paulo State being the second more grown. Their fruits have good acceptance in the market cause of the good characteristics presented as: size, attractive internal and external color, transport resistance, high juice rate and industry potential. It is necessary to study the behavior of others varieties, in order to amplify the diversity of tangerine industry, which show suitable characteristics to the fresh fruit market and that make possible different harvest season. Many tangerine varieties, selected from the Citrus Germplasm Bank of the do Centro Avançado de Pesquisa Tecnológica do Agronegócio de Citros "Sylvio Moreira"/IAC, belong to trials carried out in 15 places in São Paulo State. The Capão Bonito area, south-west of the state, is one of this places where the Nova tangelo, the Ortanique and the Murcott tangors are showing quite good results about their fruit qualities. This paper had as an objective to compare the fruit characteristics of the Nova tangelo, the Murcott and the Ortanique tangors grafted on two rootstocks: Rangpur lime and Cleopatra mandarin. Accordingly to the gotten results, is possible to conclude that Nova and Ortanique had shown weight, width, fruit shape and juice percent, similar to the Murcott. In compliance with the harvest season, the Nova present suitable conditions to fresh fruit market in May and June. By the other hand the Murcott fruits can be harvested in July to August and the Ortanique in August to September. For this reason, is possible extend the harvest season of this mandarin-like, from two to five month, occurring inclusive in a period out of the crop at the north hemisphere.
\end{abstract}

Index terms: Tangerine hybrids, rootstocks and harvest season.

\section{ESTUDO COMPARATIVO DAS CARACTERÍSTICAS DOS FRUTOS DOS HÍBRIDOS DE TANGERINA: NOVA, MURCOTT E ORTANIQUE, NA REGIÃO DE CAPÃO BONITO, SP}

RESUMO -O tangor Murcott representa 20\% das tangerinas plantadas no Estado de São Paulo, sendo a segunda mais cultivada. Seus frutos têm excelente aceitação no mercado por apresentar boas características como tamanho adequado para o consumidor, coloração alaranjada forte tanto de casca quanto de polpa, resistência ao transporte, alto rendimento de suco e potencial para industrialização. Há necessidade de estudar o comportamento de outras variedades, para ampliar a diversidade da cultura da tangerina, que apresentem adequadas características para o mercado de fruta fresca e que possibilitem diferentes épocas de colheita. Diversas variedades de tangerinas, pré-selecionadas no Banco Ativo de Germoplasma de Citros, do Centro Avançado de Pesquisa Tecnológica do Agronegócio de Citros "Sylvio Moreira"/IAC/APTA fazem parte de experimentos conduzidos em 15 localidades do Estado de São Paulo. A região de Capão Bonito, situada no sudoeste paulista, constitui um dos locais onde o tangelo Nova e os tangores Murcott e Ortanique vêm apresentando resultados bastante satisfatórios quanto à qualidade de seus frutos. Avaliou-se neste trabalho, as características físico-químicas do tangelo Nova e dos tangores Murcott e Ortanique nos porta-enxertos limão Cravo e tangerina Cleópatra. Nova e Ortanique apresentaram valores de massa, diâmetro e forma do fruto e rendimento de suco, semelhantes aos do tangor Murcott. Quanto ao período de colheita, os frutos da variedade Nova apresentaram condições adequadas para consumo em maio e junho, já os frutos de Murcott podem ser colhidos em julho e agosto e a Ortanique em agosto e setembro. Assim sendo, há possibilidade de estender o período de safra desse grupo de tangerina, de dois para cinco meses, vindo inclusive a ocorrer num período de entressafra no hemisfério norte.

Termos para indexação: Híbridos de tangerina, porta-enxertos, época de colheita.

\section{INTRODUCTION}

The world tangerine production is around 13 millions tons and China is the greatest producer (45\%). Brazil harvested 1999, 665 thousand tons half of this in the São Paulo State. São Paulo is the main growing State with 293 thousand tons followed by the states of Rio Grande do Sul, Paraná, Minas Gerais and Rio de Janeiro respectively (Agrianual, 2002).

The horticultural composition of the main mandarine-scion cultivars in São Paulo State is the following: Ponkan 60\%, Murcott 20\% and Willowleaf mandarin 15\%. (Pompeu Junior, 2001).

The Ponkan and Murcott mandarines are very appreciate in the Brazilian fresh fruit market, however its quality is lower than that of the cultivars grown in other countries and can not compete in a globalized market. More recently, in the local market, the Brazilian costumers, started to demand mandarins with better fresh fruit characteristics like better external appearance, taste and easy peeling (Boteon, 1999).

The Murcott shows some appreciable characteristics like internal and external deep orange color, good size and taste. However, it has many seeds and is not easy to peel. For this reason it has not good acceptance in the international market (Donadio, 1999).

Because of the small cultivars composition, the harvest season and fruit availability in the São Paulo State is from March through November being the top harvest in the middle of the winter time (June, July) when traditionally there is a reduced consumption of fruits in Brazil (Pio, 1993).

Due to the facts listed above, It was found necessary to study the behavior of new mandarine varieties that show better characteristics for the fresh fruit market and also extend the harvest season. Many mandarin-like cultivars from the Citrus Germplasm Bank belong to trials carried out by the "Centro Avançado de Pesquisa Tecnológica do Agronegócio de Citros "Sylvio Moreira"/ IAC. In 15 places in São Paulo State where hybrids like Nova tangelo, the Ortanique and Murcott tangors are showing quite good results of their fruit qualities. The Capão Bonito area, southwest of the state, is one of this places where the quality of fruit is exceptional. In this paper, the fruit characteristics of the Nova tangelo, the Murcott and the Ortanique tangors under two rootstocks: Rangpur lime and Cleópatra mandarin,.were compared.

\section{MATERIALAND METHODS}

For the comparison, fruits were harvested from Murcott tangor

(Trabalho 111/2002). Recebido: 01/08/2002. Aceito para publicação: 15/08/2003. Part of Master of Sciency's thesis of the author. Instituto Agronômico, Campinas, SP

${ }^{2}$ Agronomist - Embrapa Transferência de Tecnologia / Escritório de Negócios de Campinas. Av. Anchieta, 173 - cj. 41/42, Campinas, SP. F: (19) 3232-1955. e-mail: rogerio@campinas.snt.embrapa.br.

${ }^{3}$ Doutor, Researcher - Centro APTA Citros Sylvio Moreira / IAC. Rod. Anhanguera, km 158 - Cordeirópolis, SP. F: (19) 3546-1399. Financial support: CNPq and Fapesp. e-mail: rose@centrodecitricultura.br. 
(Citrus sinensis (L.) Osbeck $x$ Citrus reticulata Blanco), Ortanique tangor (Citrus sinensis (L.) Osbeck $x$ Citrus reticulata Blanco) and Nova tangelo [Citrus clementina Hort. ex Tan, $x$ (C. paradisi Macf. $x C$. tangerina Hort. ex Tan)]. Each scion was grafted on two rootstocks; Rangpur lime (Citrus limonia Osbeck) e Cleopatra mandarin (Citrus reshini Hort. ex Tan.).

The combinations above belong to an experiment planted in 1996 in the "Pólo Regional de Desenvolvimento Tecnológico/APTA" in Capão Bonito/SP, Brazil, managed with usual treatments for mandarins, without irrigation. The study was carried out in two years (2000/2001).

The soil is classified as LVD and clay texture. The altitude is 702 $\mathrm{m}$ and the climate is $\mathrm{Cfb}$, accordind Köppen classification. Rainfall is about $1.216 \mathrm{~mm}$ yearly. The yearly average temperature is $20,1^{\circ} \mathrm{C}$, being the high average $25,9^{\circ} \mathrm{C}$ and low average $14,3^{\circ} \mathrm{C}$ (Instituto Agronômico, 2002).

The experiment had eight blocks with one plant per block and fruits were harvested from three blocks. One sample was composed by five fruits, collected around the external part of the canopy at the height of 1,0 to $2,0 \mathrm{~m}$. The experimental design was the randomized blocks, three replications in a $3 \times 2$ factorial scheme, three scion varieties and two rootstocks making 6 treatments. Each replication was composed by one plant per plot.

The physical chemical analysis was carried out in the Quality Laboratory, in Cordeirópolis, SP, from May to September.

Transversal diameter (TD) and longitudinal diameter (LD) measurements were made by direct lecture from each sample using a centimeter graduate scale. The total fruits weight of the samples was obtained from a balance (model Filizola) with $15 \mathrm{~kg}$ capacity and $5 \mathrm{~g}$ sensibility.

The juice percent was obtained by squeezing the fruits in a juice extractor OIC (Organização Internacional Centenário) model OTTO 1800 , and expressing the juice weight/fruit weight in percentage. The total soluble solids (TSS) value was obtained by direct lecture in a B\&S refractometer, model RFM 330. The data was adjusted for temperature and juice acidity. The total acidity (TA) was obtained by titulation of $25 \mathrm{ml}$ juice with sodium hydroxide $(0,3125 \mathrm{~N})$ and phenolphthalein as indicator.

Statistical analysis was made for June, 1st and July, 10th on 2000 and May, 25th and August, 17th on 2001 and obtained from the following fruit characteristics: weight (g), juice content (\%), acidity (\%), TSS (Brix) and Ratio (TSS : acidity). Analysis of variance considerate $5 \%$ of probability at the $t$ test for mean comparison. For the LD and TD fruit characteristics, and shape rate (ratio LD : TD), the results presented are from data without statistical analysis.

\section{RESULTSANDDISCUSSION}

The tables 1 through 10 show the average results of fruit analysis obtained from the years 2000 and 2001. The data showed are relative to two fruit physical and chemical analysis from each year statistically analysed for weight (g), juice content (\%), acidity (\%), TSS (Brix) and Ratio (TSS : acidity). Showed are also the scions and rootstocks means.

The fruit weight $(\mathrm{g})$ of Murcott mandarine, obtained from both rootstocks, was higher than the one described by Figueiredo (1991) that is $140 \mathrm{~g}$. At the 2000 season (Table 1) no interaction effect varieties with rootstocks was observed in June, 1st. as main effect for this analysis. At the second evaluation, July, 10th, however the interaction was significative. For Cleopatra mandarin the tangelo Nova fruit weight was lower than for the other scions in this rootstock. On Rangpur lime there was no significant differences among tangerine varieties. Studying the varieties effects, it was found, that for Murcott tangor, there was no significant difference between the two rootstocks and the same happened with Ortanique. For the Nova tangelo significant differences were found between both rootstocks being the highest weight obtained on Rangpur lime rootstock.

In 2001 (Table 2), at the first analysis, the interaction effect was not significant for varieties or for rootstocks. At the August, 17th analysis, for Cleopatra, the Ortanique tangor weight was significantly higher than that of the other tangerine varieties and for Rangpur lime, the Ortanique tangor weight was just higher than Murcott tangor, being statistical equal to the Nova tangelo. Considering the varieties effects from the rootstocks, just for the Ortanique, significant difference between both rootstocks were found being the weight obtained over Cleopatra higher than that over Rangpur lime.

For the juice average (\%), for Murcott superior results were obtained when compared with the numbers described for Figueiredo (1991) for this cultivar (48\%). On the 2000 (Table 3) and 2001 (Table 4) analysis no significant effect of tangerine varieties with rootstock was observed and also no significant varieties effects and rootstock effects was found. An exception was the August, 17th 2001 (Table 4) when variety effects was found. The average juice percent obtained for Nova tangelo was significantly lower than for the others varieties that where statistical equal. . The juice results obtained for Nova where similar to those of Murcott at the time that the varieties reached their harvest point. After this moment, it was observed from the following analysis, a tendency of the Nova to lose quickly its juice content when reaching the commercial ripening. On the 2000 year, beginning in June the variety lost, in 40 days, around $15 \%$ of it juice and at the middle of August analysis it had lost $45 \%$ of it juice comparing with the June samples. According Saunt (1992) the tangelo Nova is known to show this behavior.

In the Tables 5 and 6 the TSS (Brix) results for the 2000 and 2001 years are shown. On all analysis significant interaction effects at varieties with rootstocks was observed and also was not observed rootstock effect. Except for the June 1st 2000 analysis (Table 5), in the others analysis variety effect as main effect was observed. In all the results, significant differences where verified, The Murcott showed TSS results higher than the others scions except for the May, 25th 2001 analysis (Table 6) when the Nova showed numbers lower than the others that didn't show significant difference between them. The soluble solids of Nova and Ortanique analyzed in July, 10th 2000 and August, 17th 2001, in spite of significant lower than the Murcott can be considered suitable when compared to the results described for other commercial tangerine varieties grown in São Paulo State like Ponkan and Rio willow leaf mandarin, with $40,4 \%$ and $10,8 \%$ respectively (Figueiredo, 1991).

For the total fruit acidity (\%) (Tables 7 and 8 ), no interaction effect of tangerine varieties with rootstocks neither for rootstocks as main effect was observed at any analysis. In 2000 (Table 7), variety effect on both analyses was observed and the Ortanique showed the highest values followed by Murcott as intermediate and Nova with the lowest means of fruit total acidity. In 2001, no significant effect on varieties was observed. According Figueiredo (1991), the average value of total acidity for Murcott is $0,92 \%$.

TABLE 1 - Average results for weight (g) obtained in two analyses in 2000.

\begin{tabular}{|c|c|c|c|c|c|c|c|c|}
\hline \multirow{3}{*}{ Rootstocks } & \multicolumn{6}{|c|}{ VARIETIES } & \multirow{2}{*}{\multicolumn{2}{|c|}{ Means (RS) }} \\
\hline & \multicolumn{2}{|c|}{ MURCOTT } & \multicolumn{2}{|c|}{ NOVA } & \multicolumn{2}{|c|}{ ORTANIQUE } & & \\
\hline & Jun 1st & Jul 10th & Jun 1st & Jul 10th & Jun 1st & Jul 10th & Jul 10th & Jul 10th \\
\hline CLEÓPATRA & 159,0 & $154,3 \mathrm{Aa}$ & 140,7 & $105,6 \mathrm{Bb}$ & 175,1 & $161,0 \mathrm{Aa}$ & 158,3 & 140,3 \\
\hline RANGPUR & 155,3 & $172,3 \mathrm{Aa}$ & 163,3 & $162,0 \mathrm{Aa}$ & 147,6 & $155,3 \mathrm{Aa}$ & 155,4 & 163,2 \\
\hline \multirow{2}{*}{ Means (Var) } & \multicolumn{2}{|c|}{157,2} & \multicolumn{2}{|c|}{152,0} & \multicolumn{2}{|c|}{161,4} & \multicolumn{2}{|c|}{ Jun 1st } \\
\hline & \multicolumn{2}{|c|}{163,3} & \multicolumn{2}{|c|}{133,8} & \multicolumn{2}{|c|}{158,2} & \multicolumn{2}{|c|}{ Jul 10th } \\
\hline
\end{tabular}

Values with the same letter are not differet at $5 \%$ of probability. Capital letters in lines and small letters in columns 
TABLE 2 - Average results for weight (g) obtained in two analyses in 2001.

\begin{tabular}{|c|c|c|c|c|c|c|c|c|}
\hline \multirow{3}{*}{ Rootstocks } & \multicolumn{6}{|c|}{ VARIETIES } & \multirow{2}{*}{\multicolumn{2}{|c|}{ Means (RS) }} \\
\hline & \multicolumn{2}{|c|}{ MURCOTT } & \multicolumn{2}{|c|}{ NOVA } & \multicolumn{2}{|c|}{ ORTANIQUE } & & \\
\hline & May 25th & Ago 17h & May 25th & Ago 17h & May 25th & Ago 17h & May 25th & Ago 17h \\
\hline CLEÓPATRA & 162,0 & $179,0 \mathrm{Ba}$ & 190,0 & $168,0 \mathrm{Ba}$ & 183,2 & $256,5 \mathrm{Aa}$ & 178,4 & 201,1 \\
\hline RANGPUR & 149,5 & $170,5 \mathrm{Ba}$ & 191,5 & $180,0 \mathrm{ABa}$ & 155,0 & $204,0 \mathrm{Ab}$ & 165,3 & 184,8 \\
\hline \multirow{2}{*}{ Means (Var) } & \multicolumn{2}{|c|}{155,7} & \multicolumn{2}{|c|}{190,8} & \multicolumn{2}{|c|}{169,1} & \multicolumn{2}{|c|}{ May 25th } \\
\hline & \multicolumn{2}{|c|}{174,7} & \multicolumn{2}{|c|}{174,0} & \multicolumn{2}{|c|}{230,2} & \multicolumn{2}{|c|}{ Ago 17h } \\
\hline
\end{tabular}

Values with the same letter are not differet at $5 \%$ of probability. Capital letters in lines and small letters in columns

TABLE 3 - Average results for juice (\%) obtained in two analyses in 2000.

\begin{tabular}{|c|c|c|c|c|c|c|c|c|}
\hline \multirow{3}{*}{ Rootstocks } & \multicolumn{6}{|c|}{ VARIETIES } & \multirow{2}{*}{\multicolumn{2}{|c|}{ Means (RS) }} \\
\hline & \multicolumn{2}{|c|}{ MURCOTT } & \multicolumn{2}{|c|}{ NOVA } & \multicolumn{2}{|c|}{ ORTANIQUE } & & \\
\hline & Jun 1st & Jul 10th & Jun 1st & Jul 10th & Jun 1st & Jul 10th & Jun 1st & Jul 10th \\
\hline CLEÓPATRA & 50,9 & 52,3 & 50,0 & 41,4 & 54,8 & 53,9 & 52,0 & 52,0 \\
\hline RANGPUR & 53,5 & 53,4 & 51,5 & 45,1 & 55,4 & 53,5 & 53,4 & 53,4 \\
\hline \multirow{2}{*}{ Means (Var) } & \multicolumn{2}{|c|}{52,2} & \multicolumn{2}{|c|}{50,8} & \multicolumn{2}{|c|}{55,1} & \multicolumn{2}{|c|}{ Jun 1st } \\
\hline & \multicolumn{2}{|c|}{52,9} & \multicolumn{2}{|c|}{43,2} & \multicolumn{2}{|c|}{53,5} & \multicolumn{2}{|c|}{ Jul 10th } \\
\hline
\end{tabular}

TABLE 4 - Average results for juice (\%) obtained in two analyses in 2001.

\begin{tabular}{|c|c|c|c|c|c|c|c|c|}
\hline \multirow{3}{*}{ Rootstocks } & \multicolumn{6}{|c|}{ VARIETIES } & \multirow{2}{*}{\multicolumn{2}{|c|}{ Means (RS) }} \\
\hline & \multicolumn{2}{|c|}{ MURCOTT } & \multicolumn{2}{|c|}{ NOVA } & \multicolumn{2}{|c|}{ ORTANIQUE } & & \\
\hline & May 25th & Ago 17h & May 25th & Ago 17h & May 25th & Ago 17h & May 25th & Ago $17 \mathrm{~h}$ \\
\hline CLEÓPATRA & 50,5 & 51,9 & 45,6 & 25,9 & 52,6 & 47,1 & 49,6 & 41,6 \\
\hline RANGPUR & 50,4 & 51,5 & 45,2 & 24,1 & 48,5 & 52,2 & 48,0 & 42,6 \\
\hline \multirow{2}{*}{ Means (Var) } & \multicolumn{2}{|c|}{50,5} & \multicolumn{2}{|c|}{45,4} & \multicolumn{2}{|c|}{50,5} & \multicolumn{2}{|c|}{ May 25th } \\
\hline & \multicolumn{2}{|c|}{$51,7 \mathrm{~A}$} & \multicolumn{2}{|c|}{$25,0 \mathrm{~B}$} & \multicolumn{2}{|c|}{$49,7 \mathrm{~A}$} & \multicolumn{2}{|c|}{ Ago 17h } \\
\hline
\end{tabular}

Values with the same letter are not differet at $5 \%$ of probability.

TABLE 5 - Average results for total soluble solids (TSS) (\%) obtained in two analyses in 2000.

\begin{tabular}{|c|c|c|c|c|c|c|c|c|}
\hline \multirow{3}{*}{ Rootstocks } & \multicolumn{6}{|c|}{ VARIETIES } & \multirow{2}{*}{\multicolumn{2}{|c|}{ Means (RS) }} \\
\hline & \multicolumn{2}{|c|}{ MURCOTT } & \multicolumn{2}{|c|}{ NOVA } & \multicolumn{2}{|c|}{ ORTANIQUE } & & \\
\hline & Jun 1st & Jul 10th & Jun 1st & Jul 10th & Jun 1st & Jul 10th & Jun 1st & Jul 10th \\
\hline CLEÓPATRA & 10,3 & 12,9 & 9,4 & 11,7 & 10,2 & 12,2 & 10,0 & 12,2 \\
\hline RANGPUR & 10,4 & 13,1 & 9,8 & 10,3 & 9,6 & 11,1 & 9,9 & 11,5 \\
\hline \multirow{2}{*}{ Means (Var) } & \multicolumn{2}{|c|}{10,4} & \multicolumn{2}{|c|}{9,6} & \multicolumn{2}{|c|}{9,3} & \multicolumn{2}{|c|}{ Jun 1st } \\
\hline & \multicolumn{2}{|c|}{$13,0 \mathrm{~A}$} & \multicolumn{2}{|c|}{$11,0 \mathrm{~B}$} & \multicolumn{2}{|c|}{$11,6 \mathrm{~B}$} & \multicolumn{2}{|c|}{ Jul 10th } \\
\hline
\end{tabular}

Values with the same letter are not differet at $5 \%$ of probability.

The Ratio (soluble solids : acidity) is an essential characteristic of citrus because it can help to determinate the best ripening point. According Figueiredo (1991), average Murcott Ratio is 13,7.

In 2000 (Table 9), no significant interaction effect in the first analysis from June 1st was observed, being just observed varieties effect. In this case the Ratio results of Nova was significantly the highest followed by the Murcott. The Ortanique showed the lowest results for this harvest. In the second analysis, July 10th, the interaction was significant. On Cleopatra, the Ortanique showed the lowest average values of Ratio. For this same rootstock, the results obtained for Nova and Murcott were superior and were not different between them. Considering the Rangpur lime, it was observed that, for this rootstock, the three scions are significantly different. The highest mean was obtained from Nova tangelo and the lowest from Ortanique tangor.
In 2001 (Table 10), no significant interaction effect was observed. Also no variety effect or rootstock effect was observed as main effect.

For Ortanique it was observed that this variety reaches its commercial ripening point in September. In this same season the values of Ratio for the Murcott was already high. These observations can suggest that Ortanique is later than Murcott considering the harvest season.

Considering the fruit longitudinal diameter (LD) (Table 11), it was observed that all the tangerine varieties studied didn't show "neck" in the peduncle area, common in varieties like Ponkan. The fruit transversal diameter (TD) (Table 12), represent the fruit size, used in the internal and external market as classification standard. The TD fruit means for the three scions are very similar and classified as big fruits according the international standard class belonging to the best size class for the European market showing, for this characteristic, their 
TABLE 6 - Average results for total soluble solids (TSS) (\%) obtained in two analyses in 2001.

\begin{tabular}{|c|c|c|c|c|c|c|c|c|}
\hline \multirow{3}{*}{ Rootstocks } & \multicolumn{6}{|c|}{ VARIETIES } & \multirow{2}{*}{\multicolumn{2}{|c|}{ Means (RS) }} \\
\hline & \multicolumn{2}{|c|}{ MURCOTT } & \multicolumn{2}{|c|}{ NOVA } & \multicolumn{2}{|c|}{ ORTANIQUE } & & \\
\hline & May 25th & Ago 17h & May 25th & Ago 17h & May 25th & Ago 17h & May 25th & Ago 17h \\
\hline CLEÓPATRA & 9,3 & 13,1 & 8,6 & 10,0 & 9,5 & 10,2 & 9,1 & 11,1 \\
\hline RANGPUR & 9,7 & 13,2 & 9,1 & 10,9 & 8,9 & 10,6 & 9,2 & 11,6 \\
\hline \multirow{2}{*}{ Means (Var) } & \multicolumn{2}{|c|}{$9,5 \mathrm{~A}$} & \multicolumn{2}{|c|}{$8,8 \mathrm{~B}$} & \multicolumn{2}{|c|}{$9,2 \mathrm{AB}$} & \multicolumn{2}{|c|}{ May 25th } \\
\hline & \multicolumn{2}{|c|}{$13,1 \mathrm{~A}$} & \multicolumn{2}{|c|}{$10,5 \mathrm{~B}$} & \multicolumn{2}{|c|}{$10,4 \mathrm{~B}$} & \multicolumn{2}{|c|}{ Ago 17h } \\
\hline
\end{tabular}

Values with the same letter are not differet at $5 \%$ of probability.

TABLE 7 - Average results for total acidity (\%) obtained in two analyses in 2000.

\begin{tabular}{|c|c|c|c|c|c|c|c|c|}
\hline \multirow{3}{*}{ Rootstocks } & \multicolumn{6}{|c|}{ VARIETIES } & \multirow{2}{*}{\multicolumn{2}{|c|}{ Means (RS) }} \\
\hline & \multicolumn{2}{|c|}{ MURCOTT } & \multicolumn{2}{|c|}{ NOVA } & \multicolumn{2}{|c|}{ ORTANIQUE } & & \\
\hline & Jun 1st & Jul 10th & Jun 1st & Jul 10th & Jun 1st & Jul 10th & Jun 1st & Jul 10th \\
\hline CLEÓPATRA & 1,3 & 1,2 & 0,8 & 0,9 & 1,8 & 1,7 & 1,3 & 1,3 \\
\hline RANGPUR & 1,3 & 1,3 & 0,7 & 0,6 & 1,8 & 1,6 & 1,3 & 1,2 \\
\hline \multirow{2}{*}{ Means (Var) } & \multicolumn{2}{|c|}{$1,3 \mathrm{~B}$} & \multicolumn{2}{|c|}{$0,8 \mathrm{C}$} & \multicolumn{2}{|c|}{$1,8 \mathrm{~A}$} & \multicolumn{2}{|c|}{ Jun 1st } \\
\hline & \multicolumn{2}{|c|}{$1,3 \mathrm{~B}$} & \multicolumn{2}{|c|}{$0,8 \mathrm{C}$} & \multicolumn{2}{|c|}{$1,6 \mathrm{~A}$} & \multicolumn{2}{|c|}{ Jul 10th } \\
\hline
\end{tabular}

Values with the same letter are not differet at $5 \%$ of probability.

Table 8 - Average results for total acidity (\%) obtained in two analyses in 2001.

\begin{tabular}{|c|c|c|c|c|c|c|c|c|}
\hline \multirow{3}{*}{ Rootstocks } & \multicolumn{6}{|c|}{ VARIETIES } & \multirow{2}{*}{\multicolumn{2}{|c|}{ Means (RS) }} \\
\hline & \multicolumn{2}{|c|}{ MURCOTT } & \multicolumn{2}{|c|}{ NOVA } & \multicolumn{2}{|c|}{ ORTANIQUE } & & \\
\hline & May 25th & Ago 17h & May 25th & Ago 17h & May 25th & Ago 17h & May 25th & Ago 17h \\
\hline CLEÓPATRA & 1,4 & 1,0 & 0,9 & 0,6 & 2,1 & 0,8 & 1,4 & 0,8 \\
\hline RANGPUR & 1,4 & 0,9 & 0,8 & 0,6 & 1,3 & 1,0 & 1,1 & 0,8 \\
\hline \multirow{2}{*}{ Means (Var) } & \multicolumn{2}{|c|}{1,4} & \multicolumn{2}{|c|}{0,8} & \multicolumn{2}{|c|}{1,7} & \multicolumn{2}{|c|}{ May 25th } \\
\hline & \multicolumn{2}{|c|}{0,9} & \multicolumn{2}{|c|}{0,6} & \multicolumn{2}{|c|}{0,9} & \multicolumn{2}{|c|}{ Ago 17h } \\
\hline
\end{tabular}

TABLE 9 - Average results for Ratio (soluble solids : acidity) obtained in two analyses in 2000.

\begin{tabular}{|c|c|c|c|c|c|c|c|c|}
\hline \multirow{3}{*}{ Rootstocks } & \multicolumn{6}{|c|}{ VARIETIES } & \multirow{2}{*}{\multicolumn{2}{|c|}{ Means (RS) }} \\
\hline & \multicolumn{2}{|c|}{ MURCOTT } & \multicolumn{2}{|c|}{ NOVA } & \multicolumn{2}{|c|}{ ORTANIQUE } & & \\
\hline & Jun 1st & Jul 10th & Jun 1st & Jul 10th & Jun 1st & Jul 10th & Jun 1st & Jul 10th \\
\hline CLEÓPATRA & 8,3 & $10,6 \mathrm{Aa}$ & 10,1 & $12,1 \mathrm{Ab}$ & 5,8 & $7,3 \mathrm{Ba}$ & 8,0 & 10,0 \\
\hline RANGPUR & 8,0 & $9,7 \mathrm{Ba}$ & 13,8 & $16,6 \mathrm{Aa}$ & 5,3 & $7,2 \mathrm{Ca}$ & 9,0 & 11,2 \\
\hline \multirow{2}{*}{ Means (Var) } & \multicolumn{2}{|c|}{$8,2 \mathrm{~B}$} & \multicolumn{2}{|c|}{$12,0 \mathrm{~A}$} & \multicolumn{2}{|c|}{$5,5 \mathrm{C}$} & \multicolumn{2}{|c|}{1 de jun } \\
\hline & \multicolumn{2}{|c|}{12,2} & \multicolumn{2}{|c|}{14,4} & \multicolumn{2}{|c|}{7,3} & \multicolumn{2}{|c|}{10 de jul } \\
\hline
\end{tabular}

Values with the same letter are not differet at $5 \%$ of probability. Capital letters in lines and small letters in columns

TABLE 10 -Average results for Ratio (soluble solids : acidity) obtained in two analyses in 2001.

\begin{tabular}{|c|c|c|c|c|c|c|c|c|}
\hline \multirow{3}{*}{ Rootstocks } & \multicolumn{6}{|c|}{ VARIETIES } & \multirow{2}{*}{\multicolumn{2}{|c|}{ Means (RS) }} \\
\hline & \multicolumn{2}{|c|}{ MURCOTT } & \multicolumn{2}{|c|}{ NOVA } & \multicolumn{2}{|c|}{ ORTANIQUE } & & \\
\hline & May 25th & Ago 17h & May 25th & Ago 17h & May 25th & Ago 17h & May 25th & Ago 17h \\
\hline CLEÓPATRA & 6,9 & 13,1 & 9,9 & 18,2 & 4,1 & 12,4 & 7,0 & 14,5 \\
\hline RANGPUR & 7,0 & 16,7 & 11,9 & 19,5 & 8,4 & 11,1 & 9,0 & 15,7 \\
\hline \multirow{2}{*}{ Means (Var) } & \multicolumn{2}{|c|}{6,9} & \multicolumn{2}{|c|}{10,9} & \multicolumn{2}{|c|}{6,2} & \multicolumn{2}{|c|}{ May 25th } \\
\hline & \multicolumn{2}{|c|}{14,9} & \multicolumn{2}{|c|}{18,8} & \multicolumn{2}{|c|}{11,7} & \multicolumn{2}{|c|}{ Ago 17h } \\
\hline
\end{tabular}


TABLE 11 - Average observed data results for longitudinal diameter (LD).

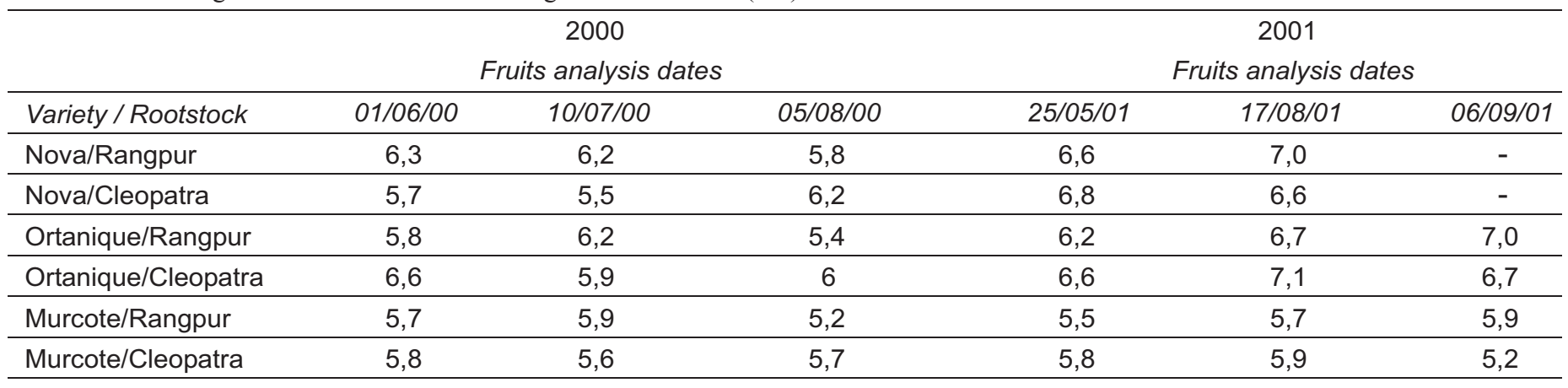

TABLE 12 - Average observed data results for transversal diameter (TD).

2000

Fruits analysis dates

\begin{tabular}{lcccccc}
\hline Variety/Rootstock & $01 / 06 / 00$ & $10 / 07 / 00$ & $05 / 08 / 00$ & $25 / 05 / 01$ & $17 / 08 / 01$ & $06 / 09 / 01$ \\
\hline Nova/Rangpur & 6,6 & 7,3 & 7,3 & 7,2 & 7,1 & - \\
\hline Nova/Cleopatra & 6,6 & 6,2 & 7,8 & 7,7 & 7,8 & 8,3 \\
\hline Ortanique/Rangpur & 5,8 & 7,1 & 6,8 & 7,1 & 8,5 & 7,4 \\
\hline Ortanique/Cleopatra & 7,9 & 7,4 & 7,3 & 7,5 & 7,4 \\
\hline Murcote/Rangpur & 7,1 & 7,3 & 7,4 & 7,1 & 7,3 \\
\hline Murcote/Cleopatra & 6,3 & 7,1 & 7,3 & 7,3 & 7,7 \\
\hline
\end{tabular}

TABLE 13 - Average observed data results for ratio LD : TD.

\begin{tabular}{|c|c|c|c|c|c|c|}
\hline \multirow{3}{*}{ Variety / Rootstock } & \multicolumn{3}{|c|}{2000} & \multicolumn{3}{|c|}{2001} \\
\hline & \multicolumn{3}{|c|}{ Fruits analysis dates } & \multicolumn{3}{|c|}{ Fruits analysis dates } \\
\hline & 01/06/00 & $10 / 07 / 00$ & 05/08/00 & $25 / 05 / 01$ & $17 / 08 / 01$ & 06/09/01 \\
\hline Nova/Rangpur & 1,0 & 0,9 & 0,8 & 0,9 & 0,9 & - \\
\hline Nova/Cleopatra & 0,9 & 0,9 & 0,8 & 0,9 & 0,8 & - \\
\hline Ortanique/Rangpur & 1,0 & 0,9 & 0,8 & 0,9 & 0,9 & 0,8 \\
\hline Ortanique/Cleopatra & 0,8 & 0,8 & 0,8 & 0,9 & 0,8 & 0,8 \\
\hline Murcote/Rangpur & 0,8 & 0,8 & 0,7 & 0,8 & 0,8 & 0,8 \\
\hline Murcote/Cleopatra & 0,9 & 0,8 & 0,8 & 0,8 & 0,8 & 0,8 \\
\hline
\end{tabular}

potential to this markets (CEE, 1989). In the Brazilian market, this TD results would be in an intermediate class because the Brazilian costumer usually prefers big tangerines. The ratio LD : TD was under 1 indicating that the fruits have flattened shape similar to Murcott (Table 13).

\section{CONCLUSIONS}

1) The Nova tangelo and the Ortanique tangor showed fruit quality characteristics similar to the Murcott tangor and showed good potential to be grown as fresh fruit in the climate conditions of Capão Bonito area.

2) The Nova and Ortanique ripening time allows to extend from two to five months the harvest season of this mandarin-likes.

3) The Nova and the Ortanique could show potential to export for their inherent qualities and because their harvest season occurs when there is no crop at the north hemisphere.

\section{REFERENCES}

AGRIANUAL 2002: anuário de agricultura brasileira. São Paulo: FNP Consultoria e Comércio, 2001. p.322-332.

BOTEON, M. Mercados de frutas cítricas de qualidade. In: SIMPÓSIO INTERNACIONALDE FRUTICULTURA PRODUÇÃO E QUALIDADE DE FRUTOS CÍTRICOS, 1., 1999, Botucatu. Anais... p. 9-

\section{1.}

CEE-COMUNIDADE ECONÔMICA EUROPÉIA. Reglamento $n^{\circ}$ 920/ 89. Diário oficial de las Comunidades Europeas, Madrid, $\mathrm{n}^{\circ} \mathrm{L}$ 97/20 de 11/abril, 1989. p.1-8.

DONADIO, L.C. Exigências para Exportação de Citros. In: SIMPÓSIO INTERNACIONALDE FRUTICULTURAPRODUÇÃO E QUALIDADE DE FRUTOS CÍTRICOS. 1., 1999, Botucatu. Anais... p. 3346.

FIGUEIREDO, J.O. Variedades de copa de valor comercial, In: RODRIGUES, O. (Ed.)Citricultura brasileira. Campinas: Fundação Cargill, 1991, v.1, p. 228-264.

INSTITUTO AGRONOMICO. Normais climatológicas de 1961 a 1990. Campinas: Centro de Ecofisiologia e Biofísica. Setor de climatologia, 2002.

PIO, R. M. Tangerinas para o verão. Laranja, Cordeirópolis, v.14, n.2, p. 539-549, 1993.

POMPEU JUNIOR, J. Rootstocks and scions in the citriculture of the São Paulo State. In: WORLD CONGRESS OF THE INTERNATIONALSOCIETYOF CITRUS NURSERYMEN, 6., 2001, Ribeirão Preto. Proceedings... Bebedouro: Estação Esperimental de Citricultura de Bebedouro, 2001. p.75-82.

SAUNT, J. Variedades de cítricos del mundo: guia ilustrada. Valência: Sinclair Internacional, 1992. 12p. 